\title{
A Heurística do Desenho e a sua Aparente Lateralidade à Arquitectura: Meadas, nós e novelos
}

Pedro António Janeiro

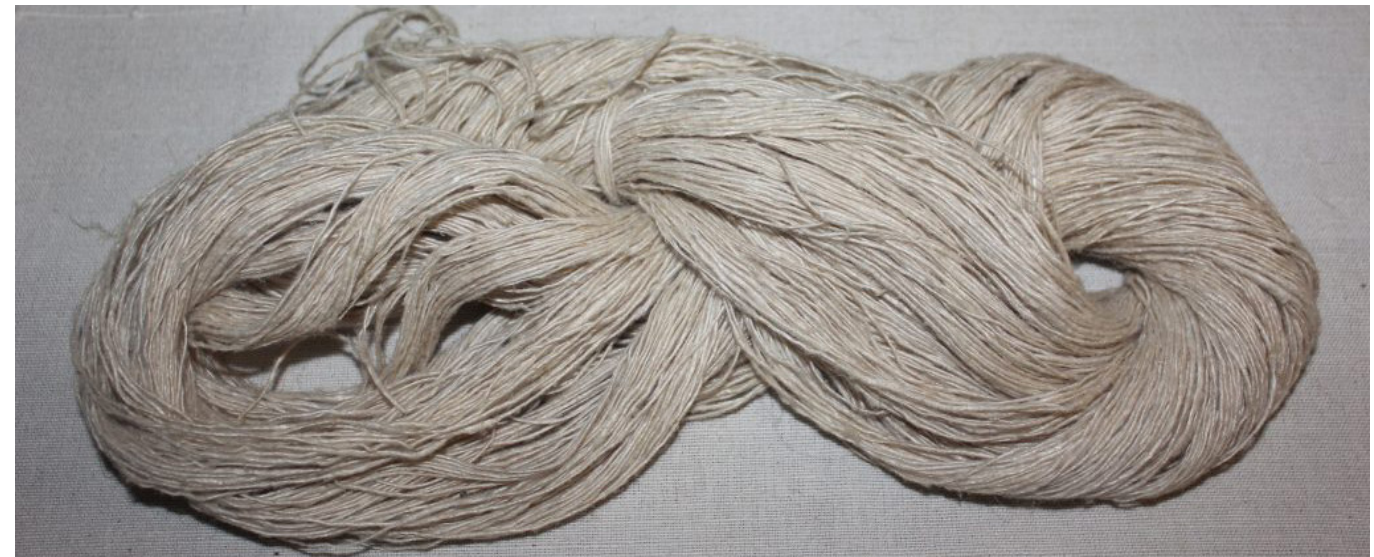


[Talvez este texto que agora apresento neste $42{ }^{\circ}$ Convénio da Uninone Italiana per il Disegno, UID, seja o meu primeiro texto em que me exponho inadequadamente - "inadequadamente", no sentido em que o tom da escrita científica, que me é pressuposta afinal, é voluntariamente deixado, esse tom, nas margens do rio de Heráclito; "inadequado" como em "anacrónico" ou "impróprio" ou "inconveniente". Porquê?

Porque o que eu quero dizer acerca do Desenho tem origem numa memória infantil e, portanto, reside num algo intangível e passante, e nesse sentido, "inadequado" porque dito, porém, discernido e escrito sobre isso - uma memória, um quase-nada. Penso poder, mesmo assim, partilhá-la convosco - mesmo apesar de tantas ressalvas e vénias académicas como prolegómeno.

Mesmo neste sentido, este texto assente nesse quase-nada, nesse sem um quase-sem-sentido volátil, evanescente, nesse quase-nada arrisco-me a partilhar essa evanescência, quase-sonho, quase intocável essa memória, hoje tantos anos depois.

Quero aqui, e antes de mais, assumir esse risco: o de ser mal lido, ou, o de ser mal-entendido, ou, o de ser mal visto. Não me importa - prefiro ser lido como sou e com as palavras com que sei escrever e com a Liberdade que a História me deu.

$[\ldots]$

Os Nós e as Tecituras e o Desenho - o tema deste $42 .{ }^{\circ}$ Convénio da Unione Italiana per il Disegno - "Un disegno per annodare e tessere", impelem-me a isso. É obrigatório, impõe-se-me esta partilha.

Corro esse risco, mas é-me indiferente! Há coisas que sinto que devem ser ditas neste erudito ambiente de Desenhadores - a atmosfera justa, direi.

$[\ldots]$

"Connettere, un disegno per annodare e tessere", traduzido da Língua Italiana para a Língua Inglesa, "Connecting, drawing for weaving relationships", não têm o mesmo significado - é ler Roland Barthes acerca das "As Línguas Naturais"(?), enfim.

Opto pela versão Italiana: "Connettere, un disegno per annodare e tessere": desenho e nós e tecituras. "Tecitura", em sentido estrito, a reunião das linhas que se atravessam num tear de urdidura; para mim, e para quem sabe desenhar o que vê, ou, para quem sabe desenhar o que imagina, é um desenho; um desenho é feito de pontos e de linhas e de manchas, como

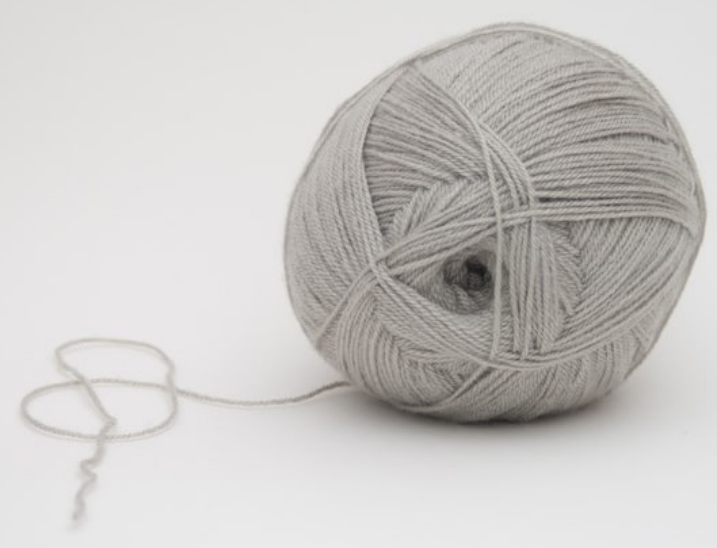


um tecido para cobrir o corpo nu; um desenho de uma arquitectura promete também esse cobrir o corpo humano, uma casa.

E, por isso, dada esta minha opção pela nossa Língua Latina, a memória de que vos falava e que pode inaugurar esta intriga tão originária como inocente é esta:]

$[\ldots]$

A memória de que falava é esta:

Lembro-me tão bem de como eu em criança abria com os braços a meada de linha de lã, desnodando-a (salvando-a dos seus nós), enquanto a minha avó, da sua mão direita envolvendo a linha que saía da meada, enrolava-a na sua mão esquerda, construía um novelo numa esfera.

Quando era criança, a minha avó Francisca era uma construtora de esferas; mas, não só esferas porque ela construía outras belezas depois com essas esferas de linha... Eu não conhecia em criança as cosmologias, nem as aristotélicas nem as ptolemaicas, de cujos modelos foram tão detalhadamente descritos, nem sabia acerca da concepção instrumentalista de Duhem sobre Ptolomeu para determinar a existência ou a não-existência acerca do conflito epistemológico entre realismo e instrumentalismo na astronomia grega, nem da Estética de Hegel, nem do Belo de Kant, nem menos ainda acerca do Éter ressuscitado de que, em Darmstadt, no dia 5 de Agosto de 1951 Heidegger falou para nos dizer Mortais entre a Terra e o Céu.

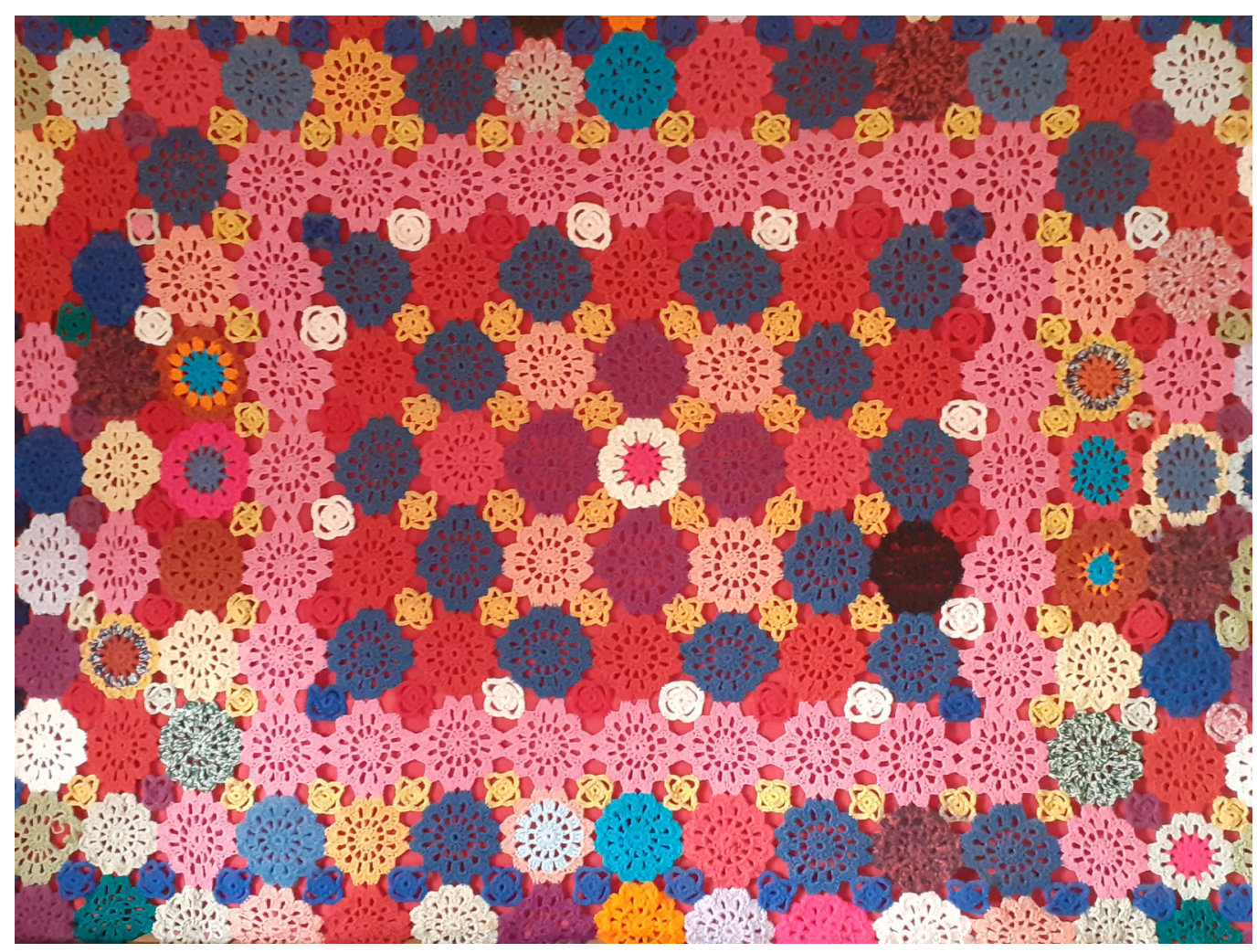

Da minha memória...:

Da meada incrivelmente estranha, anamórfica e sem sentido, embaraçada e plena de nós à esfera do novelo, corria uma linha. Dos meus braços abertos à mão direita da minha avó que enrolava sobre a sua mão esquerda uma harmonia, lembro-me do tempo (do tempo que esse processo demorava - o tempo que levava a processar o caos da meada em logos no novelo; lembro-me do tempo que demorava). Soube só desta minha inquietação acerca do Tempo do Desenho depois de ter tido contacto com a Metafísica e com as onzes 
esferas concêntricas de Aristóteles feitas de um quinto elemento inalterável, uma substância perfeitamente transparente conhecida como éter, um imediatamente para além do azul, um azul em transcendência, em coma, digamos. Desconhecia também, nessa altura, Eudoxus e Callipus.

Lembro-me desse tempo que demorava a meda até ser esfera, de ser um tempo em suspenso, um kairós [Kaıpós], um tempo sensível que não faz os ponteiros dos relógios mexerem-se - como quando eu desenhava, e desenho, casas ou corpos nus em carne, esvaídos, ou alicates ou facas que cortam, ou qualquer outro objecto visível ou imaginado, ou casas sobretudo, ou desenhos de céus de rua e outros éteres em cidades - um sentimento, um tempo fenomenologicamente sentido.

Ainda hoje para mim desenhar é isso: é resolver os nós da meada, pegar na ponta de uma linha, que mora num lápis ou numa esferográfica, e pôr por ordem (a minha ordem) o caos violento do mundo denso e complexo pleno de nós à espera de serem desatados; para depois, com a linha a correr tecer numa superfície um desenho.

Talvez por isso, o desenho me interesse mais como processo do que como produto. Interessa-me mais a linha a correr do que o novelo pronto; mais o processo do que o produto; desnodar do que os nós; o processo do entretecer das linhas do que o desenho depois de pronto. Interessa-me, portanto, o enquanto, o devir da lagarta enquanto constrói o seu casulo na esperança de ser qualquer-coisa-outra, o voar, o cumprir a sua natureza naturante (também conheci Spinoza muito depois de ser essa criança de braços abertos a ver a esfera a construir-se e a esperança na construção de outras belezas).
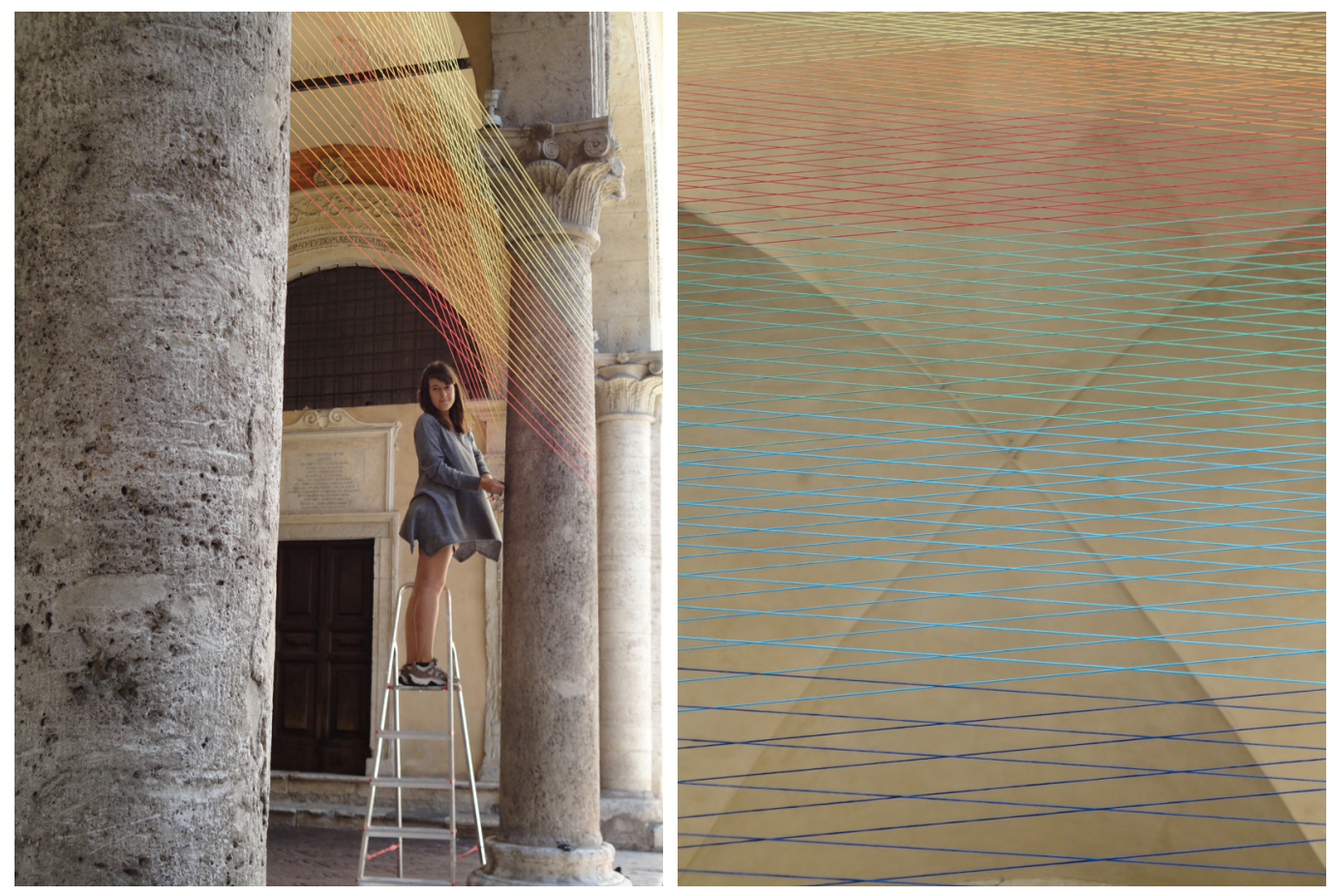

Quando desenho casas, interessa-me mais a casa que vai sendo pensada enquanto é desenhada do que o desenho acabado, pronto, que ofereço ao mundo.

Desenhar é o tempo desse processo, o momento oportuno, certo ou supremo que agarra a casa que ainda não existe mas que passa a existir mais do que não seja em promessa numa folha.

Só por isso, não há desenhos certos ou desenhos errados: há desenhos eficazes ou desenhos ineficazes. A "expressão" é a eficácia na comunicação. 
Acerca do desenhar:

Interessa-me mais o gesto que a mão faz, o quantas vezes se pára, a velocidade com que a linha viaja da meada para o novelo do que a meada ou o novelo. Interessa-me mais a resolução dos nós caóticos que o mundo ou a imaginação nos apresenta do que, por vezes, a minha lógica, ou à minha forma de dizer através de linhas, harmónicas esferas...; interessa-me, sobretudo, o tempo desse acontecer.

Quem desenha sabe que enquanto se desenha o tempo parece que pára: uma espécie de pôr o mundo entre parêntesis enquanto vemos a linha a fazer-se em coisa, uma epoché Husserliana, uma espécie de ek-stase como Heidegger a apresenta na Essência do Fundamento. Erudições à parte: prontos os novelos, a minha avó construía camisolas e mantas (havia, portanto, também em potência na desordem da meada uma esperança, um desejo, um objectivo: através do uso e do tempo da linha, havia a temperatura, a tessitura, a esperança do conforto dessas mantas ou dessas camisolas).

Fig. 5. Workshop II Tempo e il Divenire: Disegno e Interventi Artistici a Narni, 2011 .



Porém, eu quando era criança na casa da minha avó, com essas linhas de lã coloridas: atava o puxador da porta (dessa salinha onde almoçávamos) ao candeeiro; e do candeeiro à perna da mesa; e da perna da mesa, esticava bem a linha de lã, até ao prego onde estava pendurada uma aguarela azul do suíço Fred Kradolfer (uma paisagem sub-aquática de uma túlipa que os holandeses que esqueceram de inventar); e daí, desde esse prego de aço que ainda lá está, esticava criteriosamente a linha até ao abat-jour do candeeiro que estava em cima de uma mesa pequena que dava apoio ao sofá; e daí até à chave (de metal amarelo com letras recortadas a escrever OLAIO) que fechava a porta do armário onde se guardava a louça branca e azul cobalto; e daí até ali; e dali até ali, fazia viajar uma linha de lã; até que, ao fim de algumas horas de trabalho, como numa teia, eu parava maravilhado a ver como aquela sala, através da minha intervenção, tinha ganho outros sentidos. 
Acerca desses outros sentidos que a linha pode ter ou ganhar construímos, muitos anos mais tarde, tecemos intervenções plásticas na cidade de Narni, Itália, no Workshop IITempo e il Divenire: Disegno e Interventi Artistici a Narni, no IX Seminario Internazionale di Progettazione Architettonica "Architettura Citta'Territorio in Trasformazione, Tradizione - Contemporaneità - Sostenibilità, Riflessioni Progettuali Sul Recupero Dei Centri Storici", "Micro/ Macro - Architetture per il territorio ed il centro storici", em Julho de 20I I. Também uma boa memória, da qual posso mostrar algumas imagens:

Na altura eu não sabia, mas construía desenhos tridimensionais na sala onde se almoçava na casa da minha avó.

Afinal, a linha que sai da grafite do lápis não é assim tão diferente da linha que sai do novelo: em "intencionalidade" ela é a mesma; em vontade do corpo, e uso, elas são a mesma; a mesma que conta Pseudo-Apolodoro, a linha de Ariadne eTeseu no labirinto de Dédalo, na Biblioteca. "o fio no labirinto é o fio moral.", diz Deleuze n'O Mistério de Ariana.

Na sala de almoço da minha avó Francisca, com a linha eu ligava tudo a tudo como num fractal ou como num matemático 'curve stitch' de Mary Everest Boole nos finais do século XIX. A minha "instalação" (artística/desenhística) fazia com que certos aspectos da sala fossem mais vistos, mais notados. A linha que eu usava apontava para certos aspectos que para sempre, provavelmente, iriam passar despercebidos pelos habitantes daquele espaço. Isto porque os olhos seguem a linha.

Fig. 6. Workshop II Tempo e il Divenire: Disegno e Interventi Artistici a Narni, 2011 .

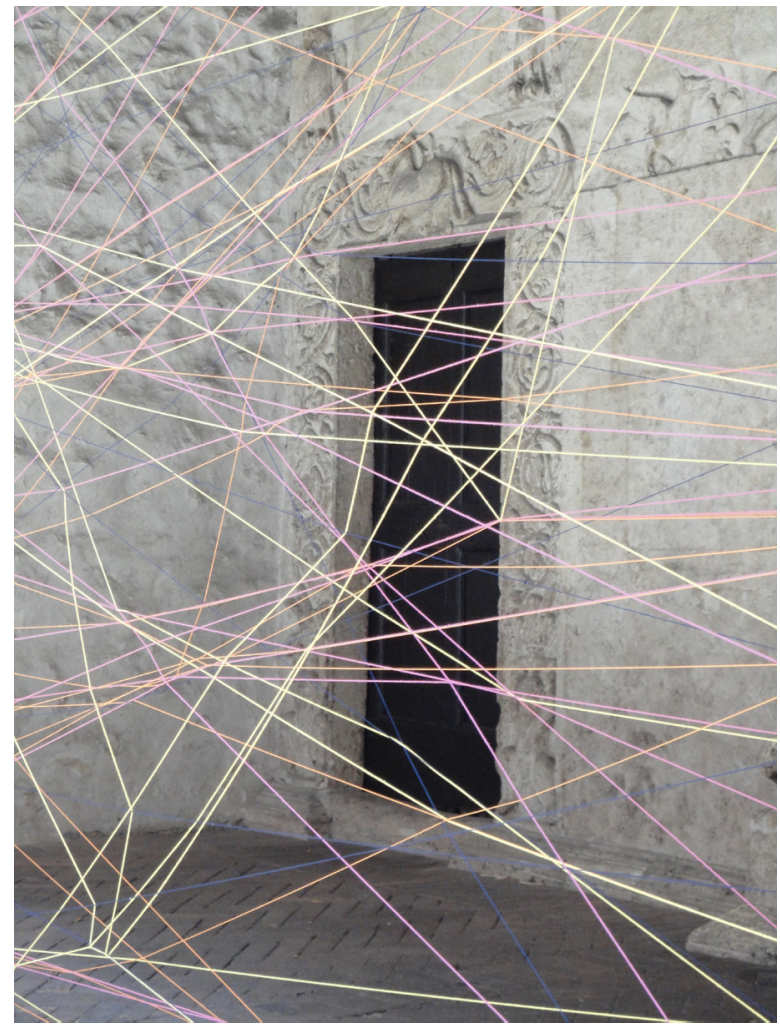

Para além dos aspectos estéticos da instalação, parece que a linha tinha quase uma função de sinalização que retirava do anonimato certos objectos ou certas características que sem ela, sem essa instalação de linhas coloridas de lã, nunca ninguém, por hábito no uso daquele espaço, teria visto. A minha instalação, o meu desenho em 3D com linha, acordava o espaço e despertava os objectos que constituíam o nosso património quotidiano; dava-lhes um outro sentido: de anónimos passavam a protagonistas; podiam ser vistos.

Essa criança, enquanto criança, morreu. 
Hoje:

A função do lápis é, enquanto o uso, largar uma linha. $\bigcirc$ cilindro de grafite que habita no escuro do meu lápis de cedro, em molécula, é um diamante (um carbono em seu estado mais puro); a sua função é, através de mim, do meu corpo, achar o brilho que escorre pelos contornos das coisas que compõem aquilo-a-que-chamo mundo. A grafite do meu lápis, ou os centímetros cúbicos de tinta da minha caneta, podem, em potência, construir uma linha com milhares de metros.

Da ponta do meu lápis ou da minha caneta, se os pressiono de encontro a uma superfície, sai, do mundo desordenado como numa meada de lã, o mundo visto e desenhado por mim, enovelado em esfera: um mundo reconstruído por linhas a dizer fronteiras entre figuras e fundos; se entrelaçadas em tramas, claros e escuros; pontos que começam e que acabam um desenho, que acabam frases se os uso para escrever.

Faço isso com a mão, como a minha avó fazia isso com a sua mão.

Penso que há, nesta memória que vos contei, um objectivo comum: a esperança.

A minha avó Francisca desnodava a meada de lã para fazer esferas para fazer mantas e camisolas; eu desnodo o mundo para desenhar casas - há um objectivo comum: o conforto do corpo que nu está à mercê, mas que com camisolas e mantas se vê provido, mas que com uma casa que o abrigue se vê defendido. Conforto, porém, não deve somente ser aqui entendido como reacção à temperatura, mas como sentir-pleno sobre o qual a Estética se debruça e sobre o qual a Arquitectura, quer enquanto disciplina quer enquanto projecto, faz.

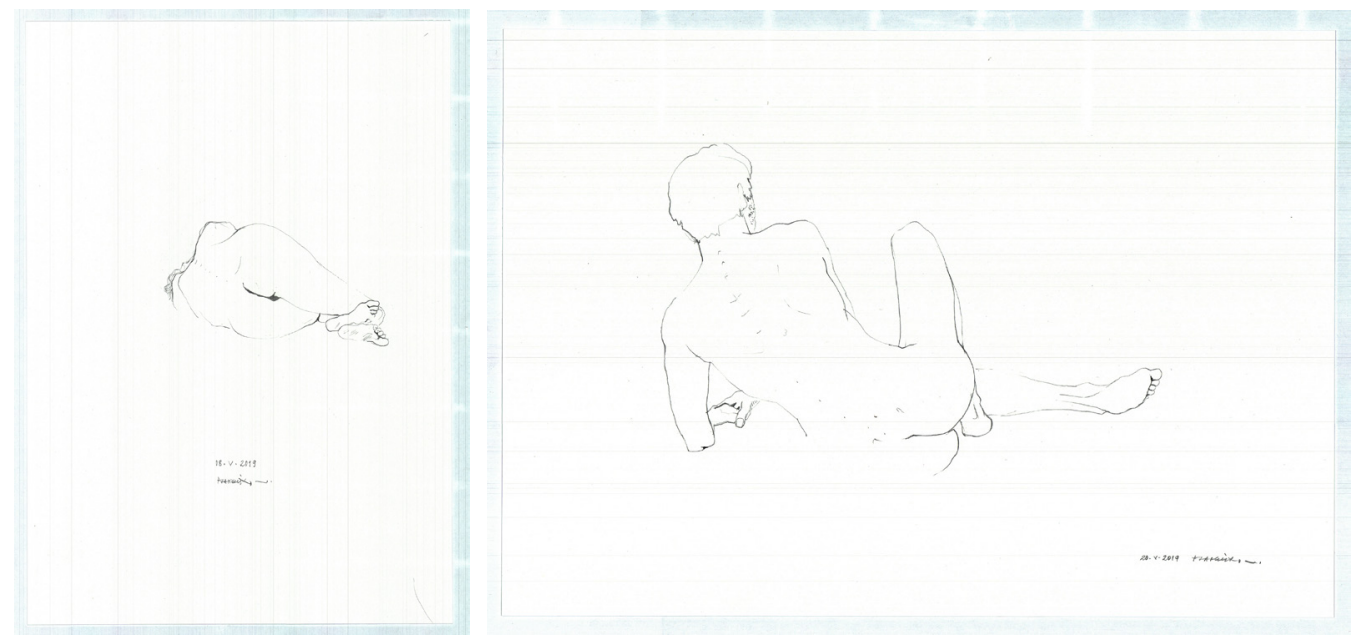

O Sentir-Pleno: o Desenhar, o Desenho e a Casa:

Pontos, centímetros, metros, quilómetros de linha. Uma linha adormecida no interior do meu lápis, caótica, sem sentido, em cilindro; mas que o meu corpo, através dela, por sua própria vontade, decide acordar as coisas do mundo tecendo.

Podemos identificar no desenho, que simula e antecipa o objecto arquitectónico, a existência de um espaço interno, um espaço virtual conquistado para-lá da superfície marcada. Para que o possamos ver será necessário recorrer a um tipo especial de desenho técnico que podemos, aqui, denominar por esquema - uma representação gráfica que sintetiza uma ideia, um facto, um conceito, um princípio, um modelo, um processo, entre outros conhecimentos, que, em certa medida, visa evidenciar e, assim, facilitar a compreensão e a comunicação das relações estruturais, hierárquicas ou de causalidade entre os diversos elementos que compõem essas informações. Podemos, assim, considerar que estas representações visuais têm um interior onde, por simulação, passam a residir os mecanismos que constituem a arquitectura como dispositivo.

Existe, portanto, na simulação sobre uma superfície, uma articulação interna cujo objectivo é o da simulação. 
Não será, por isso, motivo de escândalo se dissermos que o processo de representação vigente (assente num "estigma do realismo", como diz Francastel) de que a arquitectura faz uso e pelo qual age, teve o seu início na pintura renascentista - a pintura renascentista que, tentando encurtar a distância entre representação e representado, procurou seduzir os olhos com o objectivo de lhes estabelecer um clima total (uma experiência total do objecto a construir pelo convite do simulado); como, também, não será de todo descabido comparar o desenho arquitectónico (uma representação eminentemente técnica, porque instrumentalizada no sentido da construção) com as imagens produzidas no Renascimento. Mas, estabeleçamos esta comparação de um modo diverso: o desenho - as imagens técnicas que assistem à arquitectura -, e as imagens do Renascimento - que deram origem às primeiras -, encontram-se num patamar heurístico comum. E porque heuristicamente comum?

Porque, se por heurística entendermos a capacidade de um sistema fazer inovações e desenvolver técnicas de forma imediata e positiva para um determinado fim; porque, se a capacidade heurística pode ser descrita como a faculdade de descobrir e/ou inventar e/ ou resolver problemas mediante a criatividade e, à falta de melhor termo, um pensamento lateral, então, "heurística", parece ser a palavra adequada.

O desenho que dá serventia à arquitectura e, através da qual, o objecto arquitectónico é edificado, não é afinal outra coisa que não um pensamento lateral à própria arquitectura "à arquitectura", querendo dizer: a relação que pode ser estabelecida entre esse objecto, que essa imagem sugere e antecipa, e o homem, seu habitante. E, porquê, lateral?

Porque, afinal, o homem não habita a imagem da mesma forma que há-de vir a habitar o objecto que ela, apenas, sugere. A imagem, afinal, habita-a os olhos; o objecto arquitectónico, afinal, habita-o o corpo, e em toda a sua extensão.

Esse patamar heurístico, de que falávamos, é, por outro lado, a própria arquitectura - como gestão do espaço, (ou, melhor, como delimitação de uma parte do continuum do espaço), e como dispositivo.
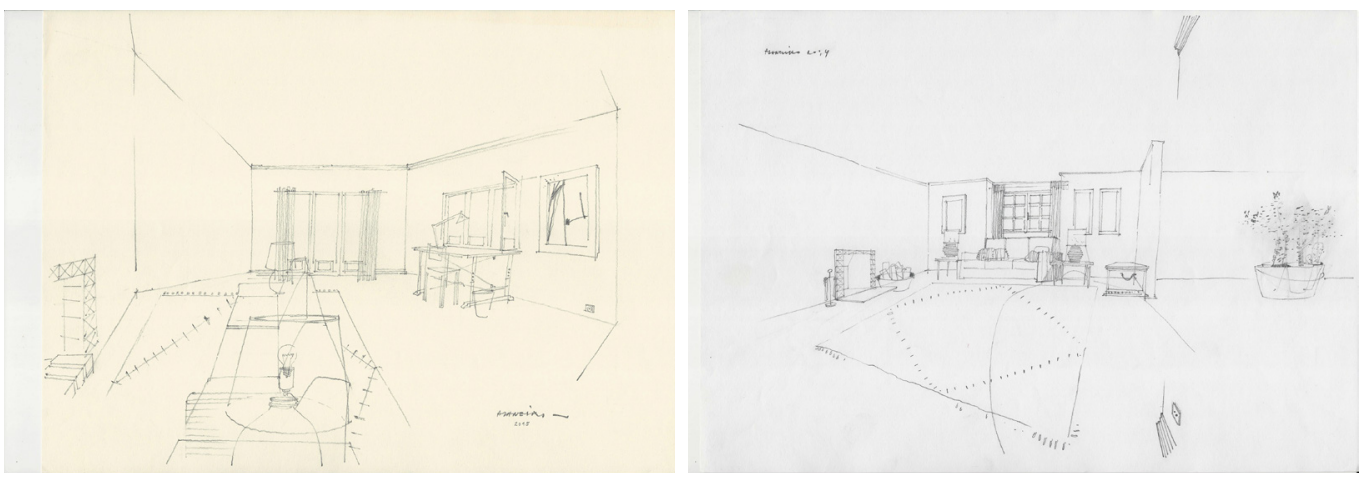

As imagens técnicas operativas na arquitectura, tal como o que sucede, afinal, com as imagens renascentistas - sobretudo as fornecidas pela pintura - procuram uma espacialização, através da simulação resumida e esquemática (no sentido em que são simplificações de uma realidade mais saturada e complexa), equivalente ou análoga à real.

A imagem, como simulação, põe em esquema (em suma, posta em síntese pela imagem) a complexidade do organismo arquitectónico; mas, ainda assim, ficará sempre aquém da experiência efectiva, dos prazeres que se podem descobrir no espaço. É a própria imagem, é o desenho ele mesmo, enquanto instrumento do projectar em arquitectura, quem pode por vezes negar essa possibilidade de prazer no espaço, quando, neste aspecto, a arquitectura deveria ser não mais do que isso - prazer ou felicidade. Quantas vezes nos deparamos com arquitecturas que são só a consequência de exercícios de desenho que ignoram o habitante? 
Enfim, comparámos as imagens técnicas da arquitectura (aquelas onde se pensa a arquitectura) com as imagens do Renascimento. Debrucemo-nos um pouco mais.

Sob um ponto de vista fenomenológico, entre a imagem pictórica e a imagem técnica, existem algumas diferenças.

Estas diferenças têm a ver com o objectivo, com o sentido, para o qual foram realizadas: se a imagem pictórica encontra a sua finalidade em si própria (ela simula um espaço para além da opacidade da superfície em que se vê configurada, e não busca mais para além desse espaço onde determinada narrativa pode acontecer); já a imagem técnica, que também simula um espaço para lá da opacidade da superfície, procura, ao fazê-lo, antever um objecto e um espaço a construir segundo os seus próprios desígnios (a imagem técnica manifesta a intenção de existência de um novo espaço). Este novo espaço é prometido na e pela imagem, pelo Desenho; e fica entre ela, que o antecipa, e a sua consequência tridimensional. É este novo espaço que sai da imagem que, tridimensionalizado, se oferece ao uso.

Até, mais: podemos considerar este novo espaço como sendo uma imagem tridimensionalizada pluridimensional. E pluridimensional porquêe?
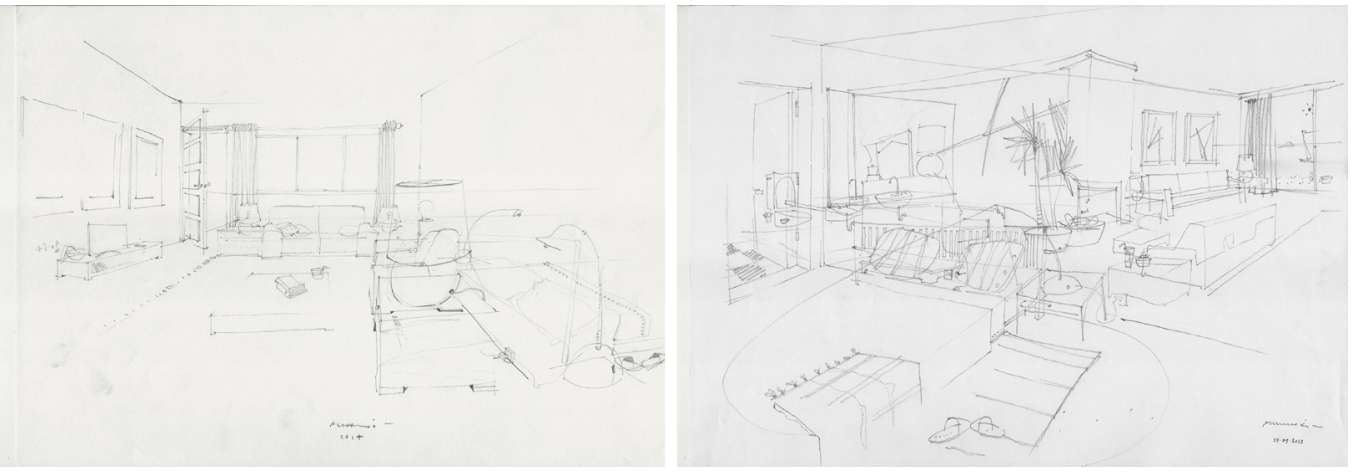

Porque são imagens que o arquitecto faz aparecer na tridimensionalidade - transferidas da simulação da imagem técnica, do desenho, para a tridimensionalidade; e pluridimensional porque, uma vez na tridimensionalidade, age sobre ele (espaço) o tempo.

O tempo - que ficava inerte no simulacro, por, do espaço, o arquitecto, conseguir apenas estabelecer contacto com uma sua representação - irrompe da imagem e manifesta-se, ainda que indirectamente, sobre o espaço outrora simulado. $\bigcirc$ espaço transferido da simulação para a tridimensionalidade vai ser constituído pelo sujeito dentro de uma dinâmica de sucessão-de-imagens-movimento-no-tempo. Da simulação do espaço ao espaço experimentável, passa-se de um patamar de imagens-inertes-no-tempo (simulacro de espaço) a uma sucessão-de-imagens-movimento-no-tempo (espaço experimentável). Patamares, obviamente, diversos.

O tempo, sempre o tempo...

Autor

Pedro António Janeiro, Universidade de Lisboa, pajaneiro@gmail.com

Para citar este capítulo: Janeiro Pedro António (2021). A Heurística do Desenho e a sua Aparente Lateralidade à Arquitectura: Meadas, nós e novelos/The Heuristic of Drawing and its Apparent Laterality to Architecture: Hanks, knots and balls of yarn. In Arena A., Arena M., Mediati D. Raffa P. (a cura di). Connettere. Un disegno per annodare e tessere. Linguaggi Distanze Tecnologie. Atti del $42^{\circ}$ Convegno Internazionale dei Docent delle Discipline della Rappresentazione/Connecting. Drawing for weaving relationship. Languages Distances Technologies. Proceedings of the $42^{\text {th }}$ International Conference of Representation Disciplines Teachers. Milano: FrancoAngeli, pp. 84 I-858. 


\section{The Heuristic of Drawing and its Apparent Laterality to Architecture: Hanks, Knots and Balls of Yarn}

Pedro António Janeiro

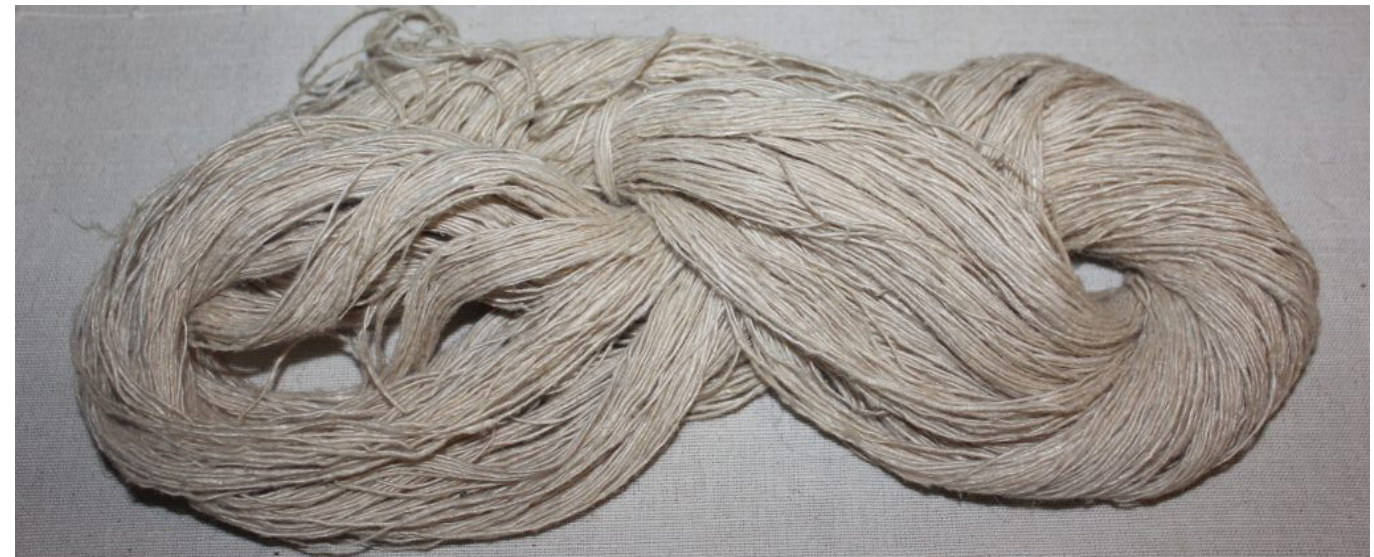


I remember so well how I, as a child, opened the hank of wool yarn with my arms, stripping it (saving it from its knots), while my grandmother, from her right hand, involving the thread that came out of the hank, rolled it in her left hand, building a ball as a sphere. When I was a child, my grandmother Francisca was a sphere builder; but, not just spheres, because she built other beauties later with those spheres of yarn... I did not know as a child, the cosmologies, neither from Aristotle nor from Ptolemy, whose models are so detailed described; nor did I know about Duhem's instrumentalist conception about Ptolemy to determine the existence or non-existence of the epistemological conflict between realism and instrumentalism in Greek astronomy; neither of Hegel's Aesthetics; nor of Kant's Beauty; nor even less about the resurrected Ether of which, in Darmstadt, on 5 August 195I Heidegger spoke to tell us Mortals between Earth and Sky.

From my memory...:

From the incredibly strange, anamorphic and meaningless hank, embarrassed and full of knots to the sphere of the ball, a line ran. From my open arms to my grandmother's right hand, that wrapped a harmony around her left hand, I remember the time (the time it took to process - the time it took to process the chaos of the hank into a logos in a ball.

I only learned about my concern about Time a Drawing takes after having had contact with Metaphysics and Aristotle's eleven concentric spheres made of a fifth unalterable element, a perfectly transparent substance known as ether, one immediately beyond blue, one blue in transcendence, in a coma. At that time, I was also unaware of Eudoxus and Callipus.

I remember the time that it took the hank to become a sphere, to be a time in suspension, a kairós [kaıpós], a sensitive time that does not make the hands of the clock move -as when I drew, and draw, houses, naked bodies in flesh, faded, or pliers or knives that cut, or any other visible or imagined object, or houses above all, or drawings of street skies and other ethers in cities- a feeling, a phenomenologically felt time.

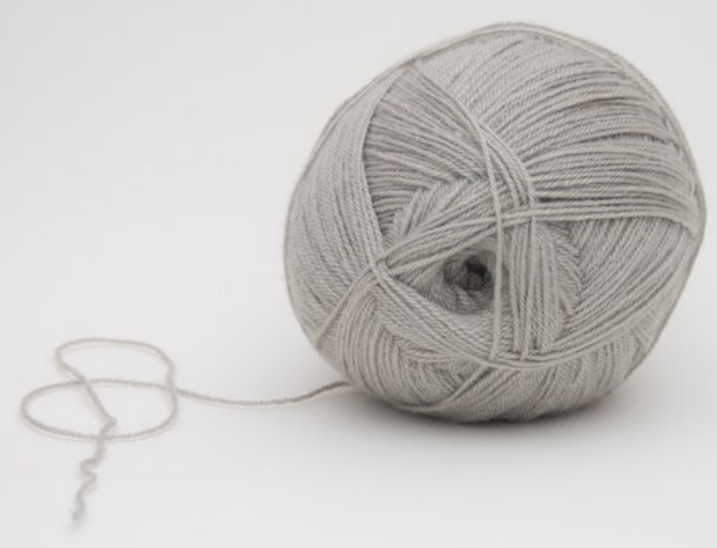


Even today for me to draw is this: it means solving the knots of the hank, taking the end of a line, which lives in a pencil or a ballpoint pen, and putting in order (my order) the violent chaos of the dense and complex world, full of us waiting to be unleashed; then, with the running line, weave a pattern on a surface.

Perhaps because of this, drawing interests me more as a process than as a product. I am more interested in the running line than the finished ball; the process more than the product; more unknotting than the knots; the process of weaving the lines than the drawing after it is done. I am interested, therefore, the process between, the becoming of the caterpillar while building its cocoon in the hope of being anything-else, flying, fulfilling its natura naturans (I also met Spinoza long after I was that child with open arms to see the sphere to be built while hopping the construction of other beauties).

When I draw houses, I am more interested in the house that is being thought while it is being drawn than the finished house, ready that I offer to the world.

Drawing is the time of this process, the opportune, right or supreme moment that grabs the house that does not yet exist, but that comes to existence as a promise on a sheet of paper.

For this reason, there are no correct drawings or wrong drawings: there are effective drawings or ineffective drawings. The "expression" is the effectiveness in the communication.

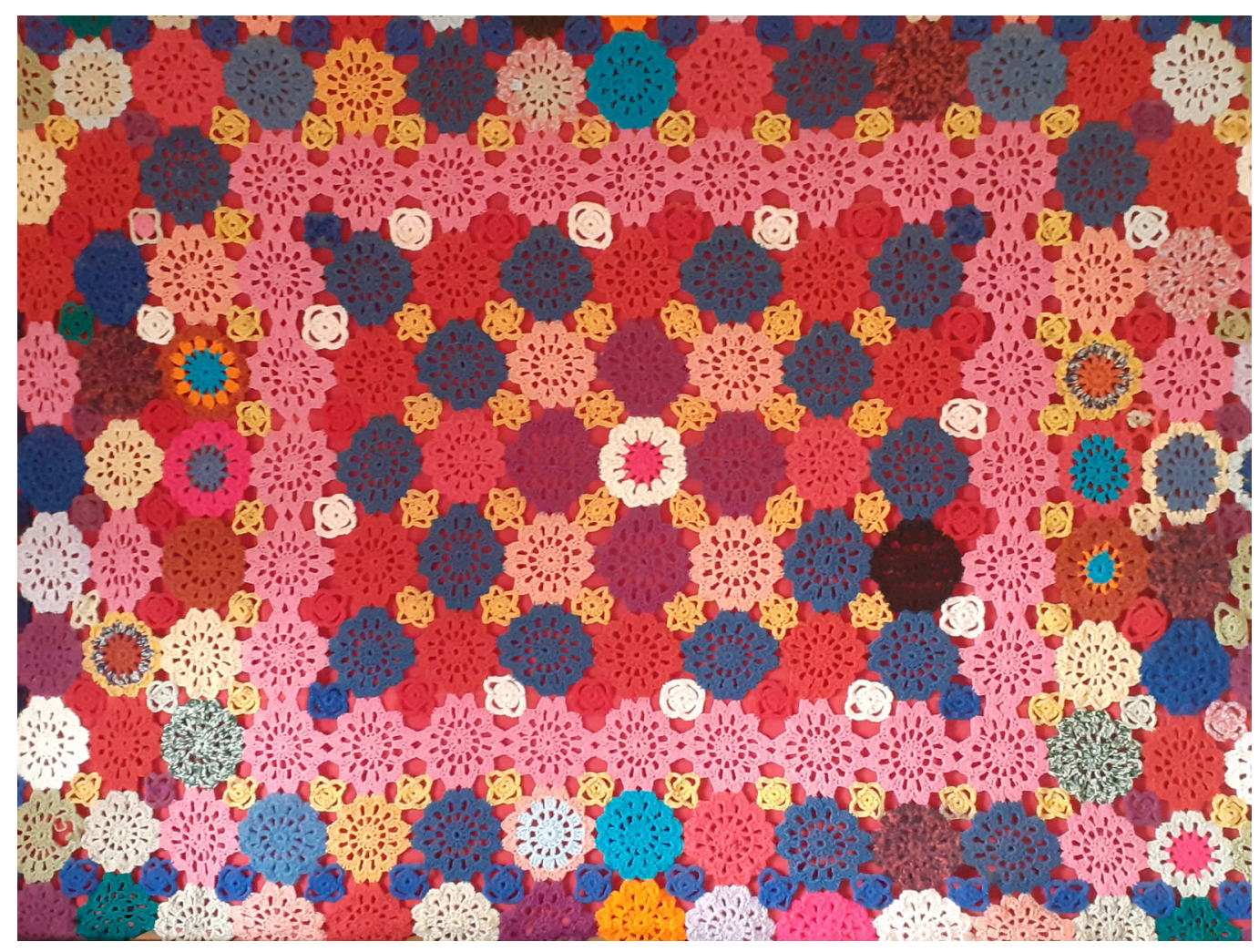

About drawing:

I am more interested in the gesture that the hand makes, how often it stops, the speed with which the line travels from the hank to the ball of yarn than the hank or the ball. I am more interested in the resolution of the chaotic knots that the world or the imagination presents to us than, sometimes, my logic, or my way of saying through lines, harmonic spheres...; I am interested, above all, in the time of this happening. 
Who draws knows that, while drawing, time seems to stop: a kind of putting the world in parentheses while we see the line being made into something, a Husserlian epoché, a kind of ek-stase as Heidegger presents it in the Essence of the Fundament.

Once the balls of yarn made, my grandmother used them to build sweaters and blankets (there was, therefore, also in potential in the disorder of the hank a hope, a desire, an objective: through the use and time of the line, there was the temperature, the fabric, hopping the human comfort of these blankets or sweaters).

However, when I was a child at my grandmother's house, with these colored wool threads: I tied the door handle (of this little room where we used to have lunch) to the lamp; and from the lamp to the table leg; and from the table leg, the wool thread well stretched, up to the nail on which was hunged a blue watercolor by the Swiss Fred Kradolfer (an underwater landscape of a tulip that the Dutches had forgotten to invent); and from there, from that steel nail that is still there, the line was carefully stretched to the lamp shade that was on top of a small table near the sofa; and from there to the key (yellow metal with letters cut out to write OLAIO) that closed the cabinet door where the white and cobalt blue plates was kept; and from there to there; and from there to there, a thread of wool was traveling; until, after a few hours of work, as if in a web, I stopped marveling at how that room, through my intervention, had gained other meanings.
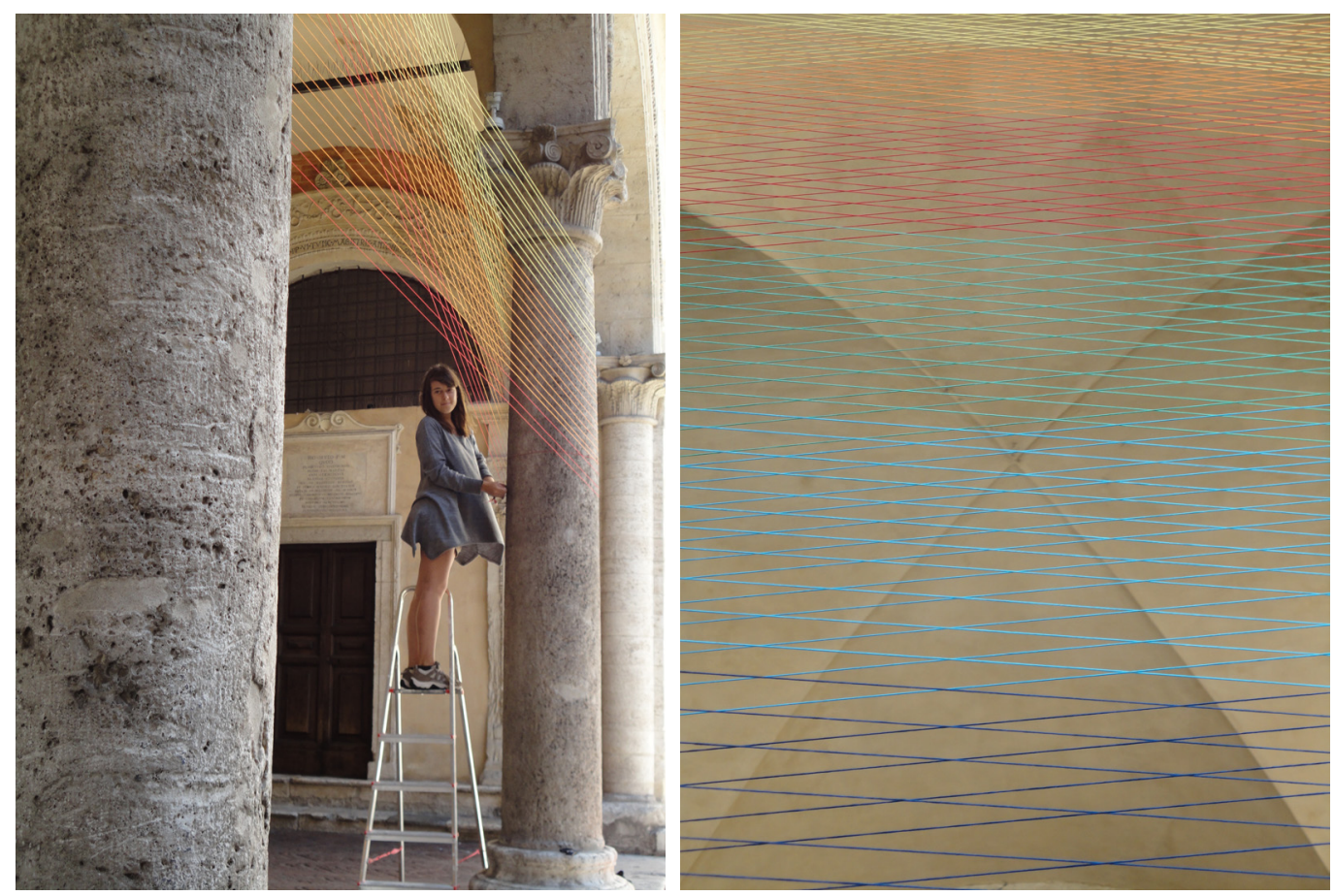

About those other meanings that the line may have or gain, we built, many years later, we made plastic interventions in the city of Narni, Italy, in the Workshop II Tempo e il Divenire: Disegno e Interventi Artistici a Narni, no IX Seminario Internazionale di Progettazione Architettonica "Architettura Citta' Territorio in Trasformazione, Tradizione - Contemporaneità - Sostenibilità, Riflessioni Progettuali Sul Recupero Dei Centri Storici", "Micro/Macro - Architetture per il territorio ed il centro storici", in July $20 \mathrm{II}$. Also a good memory, that I can show some images. 
I didn't know it at the time, but I was building three-dimensional drawings in the room where I had lunch at my grandmother's house.

After all, the line that comes out of the pencil graphite is not that different from the line that comes out of the ball of thread: in "intentionality" it is the same; in will of the body, and use, they are the same; the same that counts Pseudo-Apollodoro, the line of Ariadne and Theseus in the labyrinth of Daedalus. "the thread in the labyrinth is the moral thread.", says Deleuze in The Mystery of Ariana.

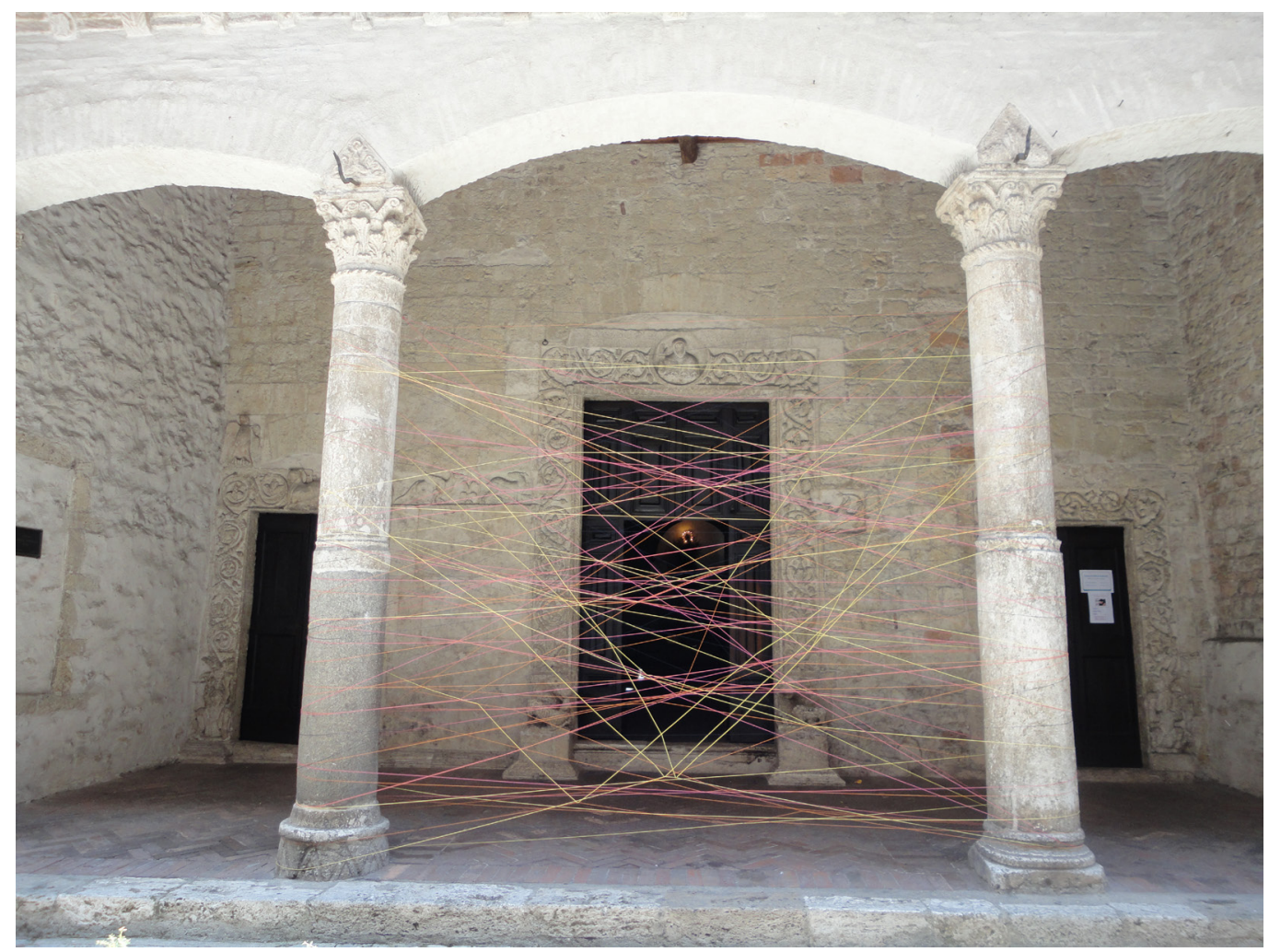

In my grandmother Francisca's lunch room, with the thread I connected everything to everything as in a fractal or as a mathematician 'curve stitch' by Mary Everest Boole at the end of the 19th century - my "installation" made certain aspects of the room to be more visible, more noticed. The line I used pointed to certain aspects that would probably go unnoticed by the inhabitants of that space forever. This is because the eyes follow the line.

In addition to the aesthetic aspects of the installation, it seems that the thread, that line, had almost a signaling function that removed certain objects or characteristics from anonymity that without it, without this installation of colored wool threads, no one would ever, out of habit in the use of that space, would have seen. My installation, my 3D drawing with line, woke up space and awakened the objects that constituted our daily heritage; it gave them another meaning: from anonymous they became protagonists; they could be seen.

That child, as a child, died. 
Today:

The function of the pencil is, while I am using it, to drop a line. The graphite cylinder that lives in the dark of my cedar pencil, in molecule, is a diamond (a carbon in its purest state); its function is, through me, my body, to find the glow that oozes through the contours of things that make up what I call world. The graphite of my pencil, or the cubic centimeters of ink in my pen, can potentially build a thousands of meters long line. From the tip of my pencil or pen, if I press them against a surface, the world seen and drawing done, curled up as in a sphere, emerges from the disordered world as in a wool hank: a world reconstructed by lines saying frontiers between figures and backgrounds; like a thread at the weaver's loom, light and dark; points that start and end a drawing, ended sentences if I use them to write.

I do this with my hand, like my grandmother did it with her hand.

I think there is, in this memory that I told you, a common goal: hope.

My grandmother Francisca was untying the hank of wool to make spheres to make blankets and sweaters; I am untying the world to draw houses - there is a similar objective: the comfort of the human body that is naked and at the mercy; but that with

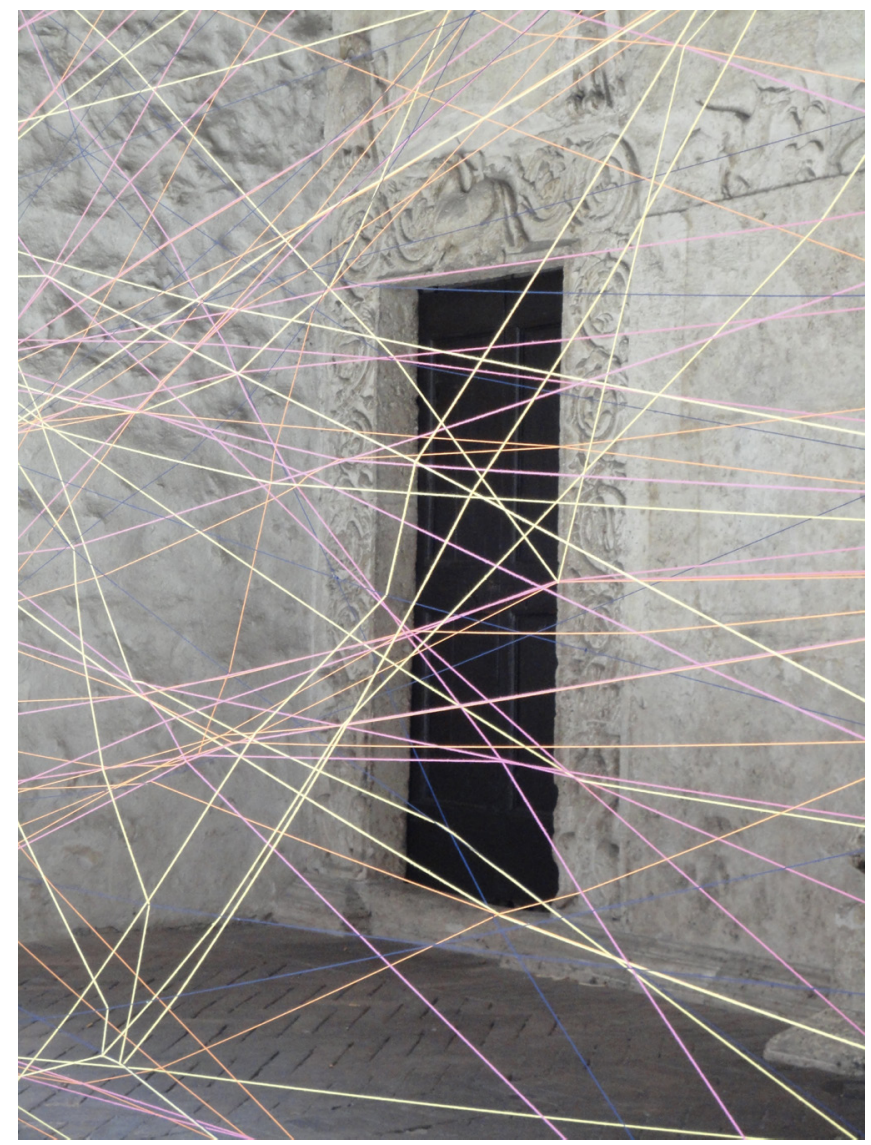

sweaters and blankets it is provided; but that with a house that shelters human bodies are defended. Comfort, however, should not only be understood here as a reaction to temperature, but as a feeling of fullness that Aesthetics focuses on and that Architecture, as a discipline and as a project, does. 
Full-Feeling: Drawing, Drawing and the House:

Points, centimeters, meters, kilometers of line. A line asleep inside my pencil, chaotic, meaningless, in a cylinder; but, that my body, freely through it, decides to wake up the things of the world by weaving.

We can identify in drawing, which simulates and anticipates the architectural object, the existence of an internal space, a virtual space conquered beyond the marked surface. In order for us to see it, it will be necessary to resort to a special type of technical drawing that we can call a scheme - a graphical representation that synthesizes an idea, a fact, a concept, a principle, a model, a process, among other knowledge, which, to a certain extent, aims to highlight and thus facilitate the understanding and communication of structural, hierarchical or causal relationships between the various elements that make up this information. Thus, we can consider that those visual representations have an interior where, by simulation, the mechanisms that constitute architecture as a device come to reside.

Therefore, in this kind of simulation on a surface, there is an internal articulation whose objective is simulation.

Therefore, it will not be a cause for scandal if we say that the current representation process (based on a "stigma of realism", as Francastel says it: that architecture use had

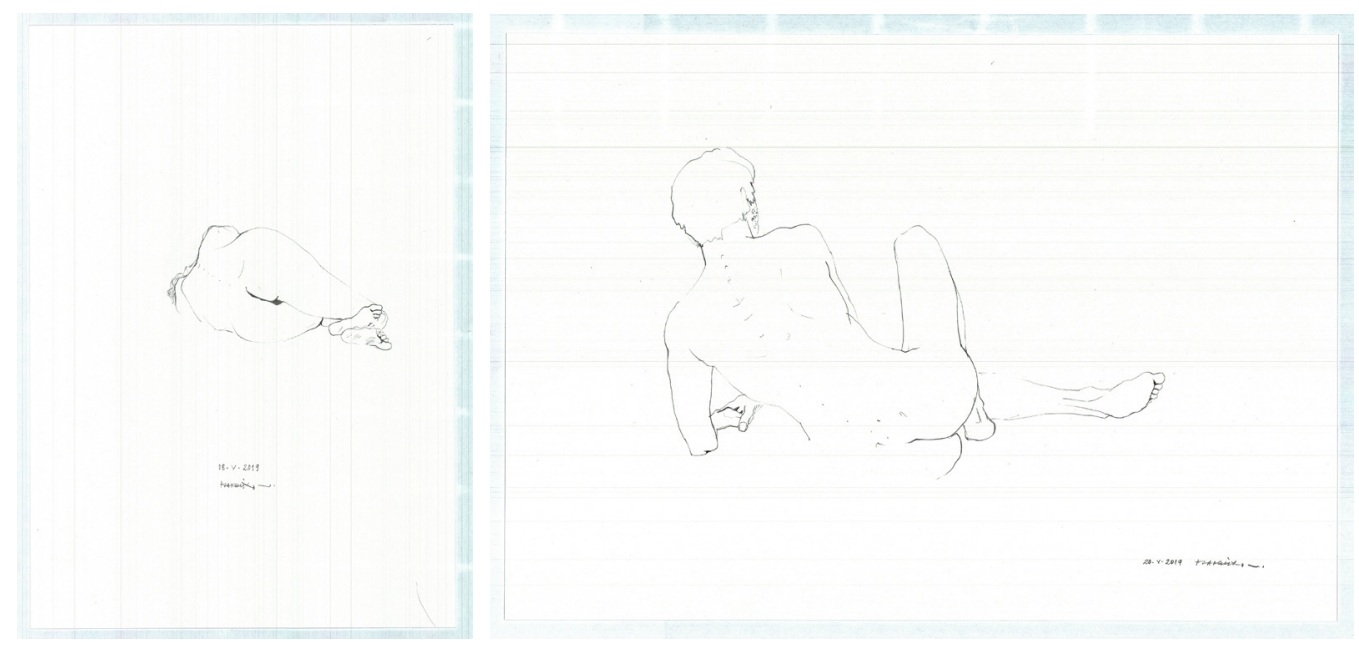

its beginning in Renaissance painting - the Renaissance painting that, trying to shorten the distance between representation and represented, tried to seduce the eyes with the aim of establishing a total climate (a total experience of the object to be built by a simulated invitation); as well, it will not be entirely unreasonable to compare architectural drawings (an eminently technical representation, because it is instrumentalized in the sense of construction) with images produced in the Renaissance.

But, let us establish this comparison in a different way: the drawing - the technical images that assist architects and architecture (and Renaissance images which gave rise to the first ones) are at a same heuristic level. And why heuristically similar?

Because, if by heuristic we understand the capacity of a system to make innovations and to develop techniques in an immediate and positive way for a certain purpose; because, if the heuristic capacity can be described as the faculty of discovering and/or inventing and/or solving problems through creativity and, in the absence of a better term, lateral thinking, then "heuristic", seems to be the appropriate word. 
The type of drawing that serves architecture and, through which, the architectural object is built, is, after all, nothing but a lateral thought to architecture itself - "to architecture", meaning: the relationship that can be established between that drawned object, which this image suggests and anticipates, and human, its inhabitant. And, why, lateral?

Because, after all, human does not inhabit the image in the same way that inhabit the object that that image suggests to be inhabited. Imagea, after all, are inhabits only by the eyes; the architectural object, after all, is totally inhabited by the body, and in all its extension.

This heuristic level, of which we spoke, is, on the other hand, architecture itself - as space management (or, better, as delimitation of a part of the locus continuum), and as a device.

Technical images in architecture, such as what happens, after all, with the Renaissance images -especially those provided by painting-, seek a spatialization, through the summarized and schematic simulation (in the sense that they are simplifications of a more saturated and complex reality), equivalent or analogous to the real.

Image, as a simulation, puts in schema the complexity of the architectural organism; but, even so, it will always remain far from the effective experience, far from pleasures that can be discovered in space, in locus. It is image itself, it is drawing itself, as an instrument of projecting in architecture, who can sometimes deny that possibility of pleasure in space, when architecture should be no more than that - pleasure or happiness. How many times do we come across architectures that are only the result of drawing exercises that ignore the inhabitant?

Finally, we compared technical images of architecture (those within architecture is thought) with the images of the Renaissance. Let us look a little more.
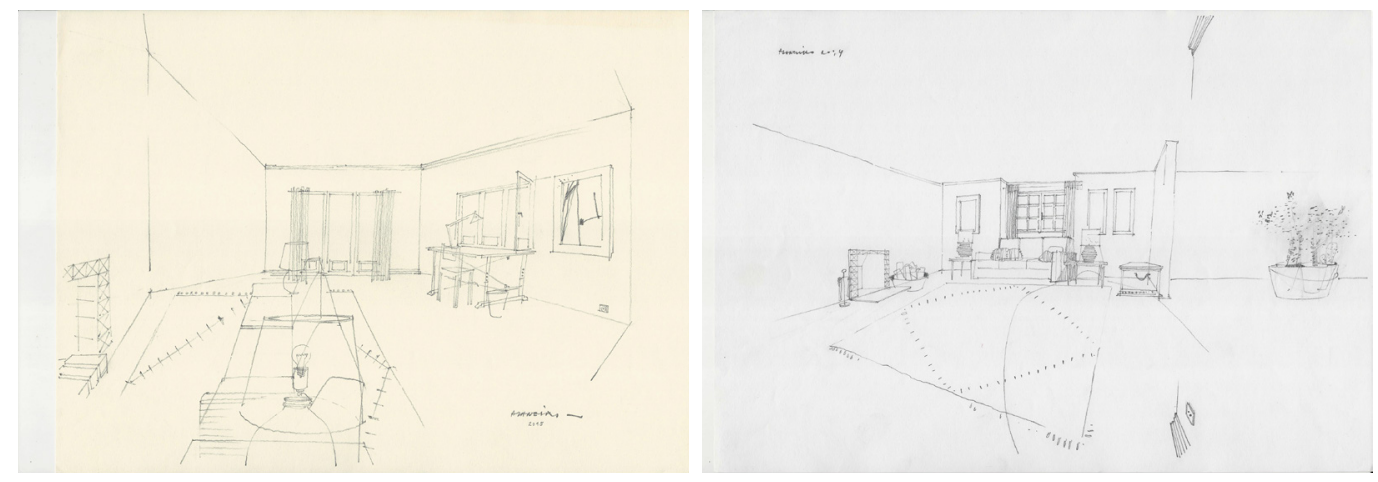

From a phenomenological point of view, between the pictorial image and the technical image, there are some differences.

These differences remain with the objective, with the sense for which they were realized: if the pictorial image finds its purpose in itself (it simulates a space beyond the opacity of the surface on which it is configured, and does not seek beyond that space where a particular narrative can happen); the technical image, which also simulates a space beyond the opacity of the surface, seeks, in doing so, to foresee an object and a space to be built according to its own way of presenting it (the technical image expresses the intention of the existence of a new space). This new space is promised in and by the image, by Drawing - and it stands between it, which anticipates it, and its 
three-dimensional consequence. It is this new space that comes out of the image that, in three dimensions, is offered for use.

Even more: we can consider this new space as a three-dimensional multidimensional image. And why multidimensional?

Because they are images that the architect makes appear in three-dimensionality - transferred from the simulation of the technical image, from the drawing, to the three-dimensionality; and pluridimensional because, once in three-dimensionality, time acts on it (space).

Time - which was inert in the simulacrum, because, from the space, the architect, is only able to establish contact with its representation - breaks out of image and manifests itself, breaks out indirectly, over the space previously simulated. The space transferred from simulation to three-dimensionality will be constituted by the human within a dynamic of succession-of-images-movement-in-time. From the simulation of space to experimentable space, we move from a level of inert-time-images (simulacrum of space) to a succession of images-movement-in-time (experimented space). Obviously different levels.

Time, always the time ...
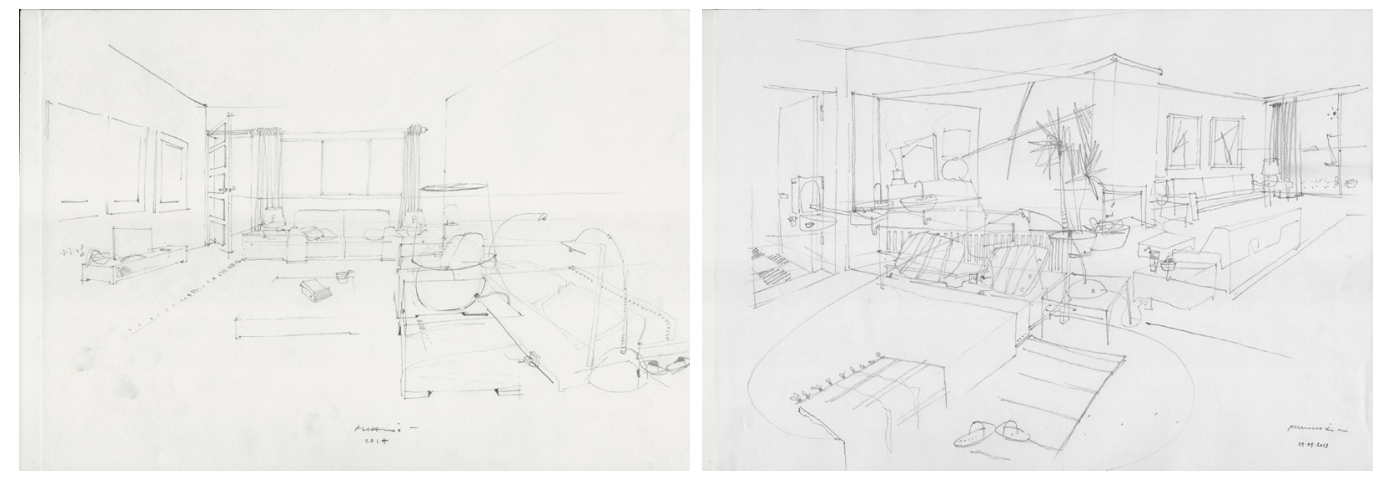

\footnotetext{
Author

Pedro António Janeiro, Universidade de Lisboa, pajaneiro@gmail.com

To cite this chapter. Janeiro Pedro António (2021).A Heurística do Desenho e a sua Aparente Lateralidade à Arquitectura: Meadas, nós e novelos/The Heuristic of Drawing and its Apparent Laterality to Architecture: Hanks, knots and balls of yarn. In Arena A., Arena M., Mediati D., Raffa P. (a cura di). Connettere. Un disegno per annodare e tessere. Linguaggi Distanze Tecnologie. Atti del $42^{\circ}$ Convegno Internazionale dei Docenti delle Discipline della Rappresentazione/Connecting. Drawing for weaving relationship. Languages Distances Technologies. Proceedings of the $42^{\text {th }}$ International Conference of Representation Disciplines Teachers. Milano: FrancoAngeli, pp. 84I-858.
} 